\title{
Journal "Shêjzat": The Path to Free Albanian Intellectual Thought in the Years of Isolation
}

\author{
Dr. Elindë Dibra
}

\author{
Department of Literature \\ University of Shkodra "Luigj Gurakuqi "
}

Doi:10.5901/ajis.2014.v3n4p71

\begin{abstract}
In the summer of 1957, in Rome, the capital of Italy, came out the first issue of the periodical magazine "Shêjzat"1, with a meaningful name, as noted by the compilers: "Hyllësi vërtytesh arbnore"2 for 18 years (57-75). Under the direction of Prof. Ernest Koliqi and under the special care of the writer and eminent scholar Martin Camaj, the journal was presented as a true encyclopedia of the ancient world and the modern Albanian world. The intellectual and cultural level of the closest collaborators of the journal "Shejzat" was European, the activity of which is covered by a strong Albanian feeling. The journal published literary creativity, folklore, studies and articles, cultural chronicles and columns in Albanian, Italian, German, English and French. The journal was founded at a time of profound isolation of Albania, where the absurdity of isolated communication with the world had forced intellectuals into exile, and thus forcing them to develop their intellectual activity and creativity in Europe, America and beyond.
\end{abstract}

Keywords: Journal, free thought, study, tradition.

\section{Introduction}

The journal " Shêjzat ", was published as a worthy successor to the temporary journals, which were published in Shkodra such as: "Hylli i Dritës", "Illyria", "Shkëndija". Although it was not published in Albania, it could be considered as the worthiest journal that contributed to the Albanian matter, culture, literature, history and traditions at a time when the "laws" of the homeland were announcing the most notable voices and minds of the nation as unwanted.

The two main cofounders of this journal had the goal as Koliqi expressed himself in one of the numbers of this journal: " Që prej numrit të parë ajo i ka shërbye besnikërisht programit të caktuem, i cili përmblidhet shkurtazi në dy pika themelore; fuqizim i vërtyteve etnike nëpërmjet kulturës dhe ndërtim ndër zemra e shqise (intelekte) t'idesë së nji Shqypnije shqiptare, ku gjindja e vëllaznueme arbnore (shpërnda në mbarë botën) të shofin shkëlqimisht të sëndertuem andrrën e poetënve të rilindjes dhe vegimin e deshmorëve në çastin e flijimit të tyre."3 ( Since the first edition it has faithfully served to the specific district program, which is briefly summarized in two basic points; empowerment of ethnic values through culture and construction of the heart senses (intellects) the Albanian Albania, where the Albanian townsfolk (distributed worldwide) may see the rebirth of the poet's dream and the vision of the martyrs at the moment of their sacrifice.). There were published 1633 articles, literary creativity, studies, reviews, bibliographies, chronicles, criticism, etc. The journal published literary creativity, folklore, studies and articles, columns and cultural chronicles in Albanian, Italian, German, English and French. The journal was founded at a time of profound isolation of Albania and therefore the main reason for its creation according to the founders was "... të kryemit e nji detyre intelektuale kundrejt atdheut, shi në kohë kur në kuadratin e historisë grepat po shënojnë nji çast rreziku jetëshues". ${ }^{4}$ (...the accomplishment of an intellectual task for the homeland was deleted through the times when history was marking a dangerous moment of

\footnotetext{
${ }^{1}$ Shejzat( le Pleiadi), a periodical, cultural, social and artistic journal. General Director: Matilda Mancinelli, editor Martin Camaj, owner Ernest Kolqi. In the year XII of publication, Peter Bartl was named editor for the German part:Meanwhile the the Head Counsil started to function: Martin Camaj, Giuseppe Gradilione, Gerhard Grim, Karl Gurakuqi, Claus Haebler, Ernest Koliqi, Giacomo Marlekaj, Rosolino Petrota, Giuseppe Schiro, Alois Schmaus, Georg Stadmuller, Giuseppe Valentini.

2 Koliqi, Ernest, "Mbas udhëhekjes së Shejzavet, në "Shejzat", 1957, no 1, pg. 2.

${ }^{3}$ Koliqi, Ernest, "Miqsija e bani ket mrekulli", "Shejzat", 1967, no 4, pg. 14.

${ }^{4}$ Koliqi, Ernest, Mbas udhëhekjes së Shejzavet, in "Shejzat", 1957, no 1, pg.2.
} 
life). To achieve this noble and strongly desired goal, the only means that will be used was the culture: "... me armën e kulturës, nëpër rreze të së cilës, çështja e shqiptare mund të zgjidhet lumnisht"'5 (through which the Albanian issue can be resolved).

This journal is welcomed not only by a large number of domestic and foreign stakeholders but also by many institutions and libraries. The notable bibliographer Willy Kamsi informs us that: "Kjo revistë $i$ është dërguar falas 100 bibliotekave dhe instituteve kulturore të botës mbarë, një tube të madhe studiuesish albanologjie dhe qindave qindave shqiptarësh në vise prej kah nuk mund të dalin pare përjashta".6( This journal is sent free to 100 libraries and cultural institutes around the world, to a large number of scholars of Albanology and to hundreds of Albanians in different countries.)

Surely among all his original works, this temporary work gave "shkëlqimin dhe dritën më të madhe figurës së Koliqit". (light and brightness to the great figure of Koliqi). " Shêjzat " conceived, founded and directed by Prof. Koliqi, originated as a cultural, social, artistic journal of prominent intellectuals and writers in exile and as such, as a result of authority and its organizational competencies "qi e pat gatue këtë brumë kaq të madh" (that had made this dough so big) came into circulation for nearly two decades. During this fairly long time" Shejzat" became the most famous Albanian culture, not only in Diaspora, but also in the free western world.

Various well-known Albanian and foreign personalities joined to give contribution to this journal. Worth to be mentioned are: Karl Gurakuqi, P. Jak Marlekaj o.f.m, the Arbëresh: Rozolin Petrotta, Zef Schiro jr, Giuseppe Valentini, G. Gradilione, C. Haebler, A. Schmaus, H.J. Kissling, G. Stadmüller, Peter Bartl and Mark Koliqi. Thanks to correspondences and connections with most well-known academies and institutes in sound libraries, the journal managed to convey the pure Albanian values and traditions without showing the restrictions and the conditions of the system. Very soon this journal became very popular in the developed world. This body found support from Albanologists such as the German Albanologist: Maximilian Lambertz, who praised " Shêjzat " as a journal with rich composition". The journal continued publication adapting to time and place to the cultural traditions of the Renaissance and especially to the journals of the period between the two World Wars. Koliqi rightly considers this journal as the bearer of the Albanian periodical "Hylli i Dritës", "Illyria", "Shkëndija", etc. It was founded and published at a time when formal Albania did not have a proper impartial scientific journal when intellectuals and the great writers of the tradition, the founders of Albanian studies institutions were declared illegal, when academic freedom was under the tutelage of control, when the new generation of official Albania was in darkness of disinformation. Thus, this publication fulfilled a huge gap and Albanian studies had a voice of their own free will, far from frames of mediocrities and without engaging into boring political demagogy during which it was founded.

" Shêjzat " of Koliqi, not only realized its goal, but exceeded expectations by becoming an important liaison body between cultural and scientific bodies that had as their object publisher Albanian studies. The journal created an excellent liaison between Diaspora of the most prominent Albanian intellectuals and between the Arbëresh of Italy and foreign Albanologists .

It was not casual that a journal might have had such a large number of collaborators, a long string of scholars and exponents of Albanian cultural life in exile, Albanian scholars and writers of Kosovo, and many such foreigners, supported the journal, as Koliqi himself writes:

"iu bane kunorë miqt anë e kand e nuk e lanë vetëm", "Trimi i mirë me shokë shumë". ("...many became friend and did not leave it alone"realizing the adage "The brave has lot of good friends").

Referring to the figures in the journal there counted a total of about 1,560 different writings as literary creativity, research articles, editorials, criticism, reviews, translations, chronicles etc.

The scope of the articles to which we refer is extremely wide and various and affects all areas of life and concerns of the nation.

In this journal a special place is dedicated to Arbër's world, thanks to the dedication of Koliqi, Camaj, Gurakuqi, besides critical writings and studies about prominent works of Albanian authors. Since the first numbers of this journal we notice the care of coauthors to bring in the original and in the translated version some of the parts of the creativity of the most prominent Italian authors such as: Dante Aligheri, Petrakra, Ungareti, and so on. In the headlines of "Shejzat" written by he himself under the nickname Hilush Vilza, through occasional columns titled: "Xixat e Shejzavef"; "Fjala qet 
fjalën", "Mendime të shkarravitura";,"Shkoqitje e pleqnime". For 18 years Prof. Koliqi "Ka shfaqur dhe shprehur mendime e opinione, ka dhënë idena e frymëzime, ka derdhë urti, dije e dëshira, ka nxitë nisma dhe veprimtari kombëtare, ka shpërblyer e kritikuar sipas rastit, ka predikuar marrëveshje midis partive politike shqiptare të mërgatës"7 etj. (He has expressed thoughts and opinions; has given the idea of inspiration; has shed wisdom, knowledge and desire; has encouraged national initiatives and activities; has criticized and rewarded accordingly; has preached agreement between Albanian political parties in Diaspora " etc.

- The perspective with it was seen and followed the development of Albanian literature was unbiased and quite accurate.

- $\quad$ Although recent studies were conducted again, this periodical presents a plethora of articles yet undiscovered and untapped by scholars of Albanian and foreign literature.

- They recorded in their chronicles the social events that serve as documentation to convey a historical and cultural message for about 20 years.

Thus the works of Prof. Koliqi in "Shêjzat" and more precisely this journal itself, founded and directed by him, serve as an open window of information and without doubt as a rich historical and cultural source, very important and irreplaceable for researchers in different fields .

Undoubtedly the greatest contribution to the publication of this journal is given by its founder, Professor Koliqi. In each issue you will find the real name or the nickname as Hilushi, Hilush Vilza, or the initials e.k, $\mathrm{K}$, etc. It is sufficient to unfold the full collection of all the years of the journal, overall known for the colossal work, image, skills and ideas of Prof. Koliqi. It is no coincidence that it was the intellectual founder, owner and famous writer Ernest Koliqi, an emeritus researcher of artistic traditions and folklore of Albania, whose writings are almost permanently in Shejzat .

\section{The Tradition on Which Shejzat was Built}

\subsection{Malli i shtampës - the inspiring muse of Koliqi}

Born and raised in an environment with tradition and culture, driven by an inner desire since childhood, as he drank by the ink smell to be close to books and printing houses, Koliqi will soon realize the dream with which he was up brought. Fate had wanted him to be near the colossus of Albanian literature at the lighted-mind personalities, taught and encouraged to work together with them and he soon could run and maintain important journals in the country. Forced to flee from Albania to Rome, not physically but mentally and spiritually, he was encouraged by the early passions, and from a willing desire to realize a cultural incentive to serve as much as he could to the homeland, which was experiencing the most terrible and crazy days of isolation. He thinks of publishing a periodical, which would serve the noble goals of all free minds, scattered throughout the free world. In the tenth anniversary of the" Shêjzat " with no little nostalgia, he recalls "Pak kemi mbetë tashma prej atyne qi dijnë me hollsina të kaluemen për sa u përket orvatjeve në lamije të fletorizmit shqiptar. Po bahen dyzet e tetë vjet qi hyna s'pari në vallën e publicistavet dhe kam shum kujtime të lidhuna me ngjarjet ma me randësi t'atdheut". ${ }^{8}$ (Few have remained that know in details the obstacles that we have passed through in Albania. It is almost for forty eight years that I have become part of the best writers of Albania and I have lots of memories related strongly to the most important events of time.). Having a magazine of himself, Koliqi, " was given the opportunity to mark the most important memories enabling historians to recognize and fairly judge the atmosphere of some periods of national life. "Dokumentat historikë, nëpër të cilët ngjallet kalesa, njomen e shëndrisin kur i rrethon atmosfera e ndiesmave vlim- plote, e ngjyrave, e shijes dhe fryma dalluese e vargut të ndodhinave, qi përban pelhurën e historis"9. (Historical Documents, through which transitions are vitalized, become soft and bright when surrounded by the atmosphere of colorful feelings, the taste and the distinctive spirit of the string of events, that constitutes the fabric of history."

In parallel Prof. Koliqi reminds us of Archbishop Pjetër Bogdani, when in 1685, the creator of Albanian literary prose was forced to exile from Albania and escape to Turkish persecution. He settled in Padova and was generously hosted by Cardinal Grigor Barbarigu, a quite famous active prelate originating from a noble family among the best known of Venice. The Archbishop of Skopje forced to leave the homeland, had taken with him the manuscript of his work

\footnotetext{
${ }^{7}$ Gurakuqi, Karl, Ernest Koliqi, "Shejzat" - Vjeti VII, Maj-Gusht 1963, no. 5-6-7-8, pg. 164.

${ }^{8}$ Koliqi, Ernest, Shkoqitje e pleqnime - Malli i shtampës, "Shejzat ", no 9-12,X,1966, 298.

${ }^{9}$ Idem
} 
Cuneus Prophetarum . "Deshironte t'a shtypi". ". Here are his touching words with which he describes the burning desire he had for the publication of the work : "M'aviti ky zot fort i dashunë (Kardinal Barbarigu), tue më lëshuem ndë Padovë, Shtëpij, Trimënij, Kual e Koçij si doe une me u sherbyem: Ma une, tue pasun maln e shtampësë, gjithë atyne u ktheva faqen, veç ju lutshe të më shtampohej libri..." (this strong beloved god ( Cardinal Barbarigu ) took me close, giving me a shelter and everything I needed in Padova: And I faced everything praying that my book be printed...)

This longing, nor less nor more already became one with the Koliqi phenomenon.

\subsection{Overview of the predecessor of "Shêjzat ".}

\subsection{Ndoc Nika printing office}

In the neighborhood of Gjuhadol in the city of Shkodra, an old neighborhood where Koliqi was born, on the first floor of a building owned by an old family of Shkodra was Ndoc Nika printing office. Very soon this printing office would wrap the small boy with a magic effect, which would not relinquish for life .. "Nuk ishte zëja e shtypshkruesit qi më tërhiqte. Më dridhej përmbrenda nji ndiesi e çuditshme së cilës n'at moshë nuk muishem me i dhanë dum. Kur u rrita kuptova se shtypi asht mjet shfrimi qi fashitë të brëmet e deshirit qi ta trondisin menden e ta mundojnë shpirtin tue e nxitë me derdhë e shprazë në letër shka vlon në thellësit ma sekrete të vetvetes. Nji palë njerz i rrene mendja (e unë jam nji sijsh) se kanë dishka për të thanë dishka qi lëvizë n-errësit e nënvetedijes. Këta njerz vuejnë po s gjeten rasën ta qesin për fushë, atdishka, me anë të shtypshkrimit. La folle du logis, fantazija, shpesh e merr në qafë njerín. Por gabon ai qi mendon me na dënue:"10 (It was not the sound of the printing office that attracted me. I trembled by a weird sensation what was that I could not do at that age. When I grew up I realized that printing is a way of release from the thing that frustrates our souls and minds encouraging them to emerge from deep inside and pour on paper. Some people (I am one of them) think that they have something to say, something that moves in the darkness of the subconsciousness. These are people who suffer for not finding the possibility to print what they think. La folle du logis, phantasy sometimes tricks people. Wrong is he that condemns us:"11

This printing office, his most interesting game of childhood, wrapped in a magic veil, will accompany him for a whole life. Very soon other printing offices began to appear: Ernest Koliqi, whose letters will remain as the most precious Albanian and European cultural and literary heritage. A lot of printing presses, at home and abroad, published critical studies, various literary articles, essays, journalism, historical documents, chronicles, and reviews. With a particular passion, he would frequently wake up on the grate, which never gave him displeasure, but quite the contrary delight and passion. He loved printing from the early childhood to the last days of his life. Together with his brother in-law Petro Vuçani, he checked and took care that every single letter of the journal " Shêjzat " emerge accurate and clear .

\subsection{Journal "Sy-kalthër"}

Since high school, while he was studying at a high school in northern Italy, along with a group of friends, he published the first - monthly literary journal "Noi, Giovanni ... " His writings were well received since at the beginning . "Kështu qi përpjekjet e para si poet e si botues zunë fill për së mbari... Ato fillesa të mbara më kanë trimnue ma vonë me marrë pjesë ndër nisme botuese. Nganjiherë $i$ thom vetes së suksesi i botimeve të para qe ai qi më mori në qafë."12 (So my first efforts as a poet and publisher got the right way... Those first successful efforts had encouraged me later to engage myself in publishing initiatives. Sometimes I think to myself that it was this first success that tricked me.)

\section{5 "Ora e Maleve"}

"Ora e Maleve", the very popular journal of Shkodra, which played a key political role for a period of time throughout our country, recognizes Koliqi as the principal founder, having its roots in a room of Koliqi in early 1923. Father Anton Harapi, Nush Topalli, Dom Lazer Shantoja were among the cofounders who cared for the welfare of the journal. The beginnings had mostly literary character but quickly this journal adapted to the political needs of the country and its goal became

\footnotetext{
${ }^{10}$ The same.

11 the same.

12 Idem, pg. 298.
} 
politics: A broad group was assembled at "Ora e Maleve ", which included in its bosom , religious, social and economic powers of Shkodra, and all its regions. It was Luigj Gurakuqi, who already headed the group. "Shkodra nuk njofti kurr stinë ma të lulzueshme me mugullime qellimesh e vullnetesh për nji përparim të njimendtë qytetnuer. Shkodranët pa dallim besimesh, klasash shoqnore, kulturash, me lagje të qytetit e me katunde e me male kreshnike, mblidheshin tok rreth Gurakuqit, bashqytetarit zëmër-madh e mende-ndritun, qi dinte me pajtue në shkrime në sjellje e në veprimtari ndertuese tharme jetike të traditave të shëndoshta me nevojët e kohës modeme. (Shkodra never recognized a better flourishing season with the unique purpose of a civilized progress. Shkodra citizens regardless of beliefs, social class, or culture, brave people of the mountains gathered in the city 's neighborhoods together around Gurakuqi, the open-minded and kind-hearted citizen, who knew how to harmonize in writings, in behavior and in many other activities real life traditions with the needs of modern times. Koliqi was appointed as editor by Gurakuqi and Fishta, which greatly encouraged him to work diligently and professionally. He spent hours and days on papers losing the sense of time at the printing office, which was located in the courtyard of the Franciscan primary school.The working group of the journal consisted of the most beloved and eminent personalities of time. Father Gjergj Fishta, Father Ndre Mjeda, Luigj Gurakuqi, Father Anton Harapi, Shuk Gurakuqi, Kolë Kamsi, Father Bemardin Palaj Father Lazër Shatoja, Ernest Koliqi and the master of printing Gjon Shypnia, as he was known, as a result of his strong engagement in politics. This journal significantly influenced the people, spreading knowledge and culture and simultaneously giving light and bright thoughts to many people during a confusing political time. "Në nji atmosferë të tillë e me të tilla mjeshtra të shkelqyeshem pata fatin të baj rishtarin (noviciat, apprentissage) sifletorar e si shkrimtar. E shpesh më kjan zëmra se nuk përfitova sa duhej. Ndër dyshime qi nganjiherë më tundojnë mbi ardhmëni të Shqipms e të shqiptarizmit, më mjafton të përtrijë në mende at kohë e ata njerz e at popull për me forcue në vete besimin mbi fate t'atdheut. Tharmet e asaj stine nuk do të shkrumohen, s'kanë si m'u përtha sidomos pse u rinë e u njomsuen nga nji gjak bujar e i çmueshëm ke s've". ${ }^{13}$ (In such an atmosphere with such excellent masters I was fortunate to "baj rishtarin "(noviciat, apprentissage) as writer. I often suffer from the feeling that I did not do the best. In my thoughts, which sometimes made me doubt about the future of Albania and Albanian feeling, I just let myself recall that time and those people just to reinforce in myself the faith of the fate of my homeland.

\subsection{Journal "Bashkimi"}

In June 1924 , after being elected private secretary of Gurakuqi, and after having met with some representatives of the Union society founded by Avni Rrustemi in which he was already part, Koliqi founded the journal " Union ". This was another new experience for the co founder of the "Ora e Maleve". The young Koliqi got enthusiastic from Noli government and believes at the new light that will light up the place. He himself explains that: "'Shoqnija "Bashkimi" mbante premtimin, qi i caktonte vetë emni, dhe Toskë e Gegë, për të parën herë, lirisht rrijshin bashkë, bisedojshin, rrahshin problemet e kombit... Sidoqoftë vija qi i caktoi vetes fletorja "Bashkimi" qe thjesht kombtare, vërté me disa parime të preme shoqnore, por tue pasë qëllimin e ngulun m'u përmbajtë mbrenda hullis së traditave dhe me i u përshtatë rrethanave të vendit." "14 Bashkëpunimi me fletoren" Bashkimi" zgjeroi mendësinë e Koliqit dhe i mundësoi atij vështrimin e problemeve të ndryshme në një frymë më të gjerë kombëtare. (The "Bashkimi"Union held the promise, that was settled, and Tosk and Gheg, for the first time, freely co existed, talk together facing nation's problems ... However the goal that the journal "Bashkimi" appointed to itself was merely national, indeed with some social principles, but with the main purpose on focusing on traditions and adapting to country circumstances. " The cooperation with the journal "Bashkimi" expanded the knowledge of Koliqi and enabled him to face different problems in a broader national spirit.

\subsection{Journal " Illyrija "}

" Illyrija ", is the next literary journal, which recognizes the group's co - founders again, already -known Ernest Koliqi, who was selected by Asim Jakova, director of the magazine and also the person who took special care in developing the journal under the difficulty of monitoring the system of time. This literary journal that gathered writers from Shkodra, Korça, Gjirokastra and Vlora and from other regions of Albania soon became known in literary circles in Tirana, Shkodra and elsewhere. Authors of sturdy clear conviction such as: Branko Merxhani, researchers in knowledge on issues of

\footnotetext{
13 lbid, pg.302.
}

14 Ibid, pg. 303. 
sociology such as Stefan Shundi, writers of great literary power as Anton Logoreci, eminent figures influenced by the literary Anglo-Saxon style such as Karl Gurakuqi, a familiar voice in Albanian linguistics, Odysseus Pascal equipped with powerful artistic values, addicted to the European Symbolists school, would be brilliant for journal "Illyrija", which thanks to the generous contribution of directors, Asim Jakoves reached breakthrough in worldly circles, especially the capital, these regions which until that time mostly preferred to read literature in foreign languages. Never before Albanian literature had attracted the attention of so many readers in that time. Many young people and among them, Migjeni, conducted their affirmation in this journal. "Branko Merxhanit e mue nuk na shpëtonte cilsija e poezis së Migjenit, e burueme me frymzim autentik nga nji ndieshëmeni e thjeshtë dhe e stërhollë për mjerimet njerzore e padrejtësit shoqnore. Na tërhiqte butësija e disa përfytyrimeve të freskëta papritmas t'acarueme e të këputuna nga nji plasje vrumulisjesh e kushtrimesh kryengritëse. Për t'i a vu në dukje talentin, i a vëndueme vjerrshën e njoftun: "Të lindet nji njeri..." në faqen e tretë." ${ }^{5}$ (Branko Merxhani and I always recognized the quality of poetry of Migjeni, which flowed from an authentic inspiration with a simple and subtle sensation for human misery and social injustice. We were deeply attracted by the softness of some fresh images suddenly destroyed by insurgent slogans. To mark his talent, we presented the famous poetry: "Të lindet nji njeri..." on the third page." With this fact Koliqi himself rejects communist voices of criticism, who tried to run absent charges against Koliqi attitude towards Migjeni creativity.

"Illyrija", do të mbesi në historin e letrësis s'onë dishmija e nji këthese si në përmbajtje ashtu në struktura formale t'artit e të shkrimit"16. ( "Illyrija" will remain in the history of our literature the evidence of a curve in composition as well as in formal structures of art and writing.)

\subsection{Journal "Shkëndija"}

With the main purpose that the pure literary Albanian movement could not be interrupted but continue, in 1939, in Tirana, Koliqi decided to draft another temporary journal. "Shkëndija" was titled the newest journal , for which the director chose as editor Nexhat Haki, a young writer with artistic talent and national values .

The program of this journal according to the leadership of this journal will focus on three main points:

1) Constant investigation of the Albanian soul;

2) Sublimation of the healthiest instincts of the nation;

3) Linguistic attempts towards revitalization of the words of our "old language" through development of new ideas.

The invitation directed to the Albanian intellectual minds to write for the journal was welcomed and had a positive echo. For a short period of time, readers had the pleasure to read writings and creations of the most eminent personalities of the time, Father Gjergj Fishta, Mustafa Kruja, Lasgush Poradeci, Et'hem Haxhiademi, Vangjel Koça, Namik Resuli, Shantoja, Asdreni, Aleksandër Xhuvani, Karl Gurakuqi, Simon Shuteriqi, Kudret Kokoshi, Bernardin Palaj, and also Vedat Kokona, Pashko Gjeçi, Nikë Barcolla, Nonda Bulka, Arshi Pipa, Skënder Arrëza, Sterjo Spasse, Sotir Çaçi, Syrja Minarolli, Filip Engjell Ndocaj, Perikli Mborja, Foni Qirko, Gaspër Pali, Asim Lohja and many others. Carefully noting all the various personalities that freely expressed their voice and bravely expressed their opinion, we conclude that a good part of them were declared enemies of the country after the changing of the system, which was the greatest paradox against their will in a free and civilized Albania. Some of them were imprisoned; others were eventually forced to flee from their home country while the rest were forced to serve the system of time. Mjafton të theksojmë se kolekcjoni $i$ saj i sherben shkruesit të historis letrare t'onë, kur kjo heret a vonë ka për t'u shkrue me këthiellti mendjeje e pa gjykim (pasion), si nji përmbledhje dokumentash letrarë t'aftë për të tregue atmosferën pak të njoftun t'asaj kohe. "Shkëndija" do të duket si nji hallkë qi lidhë tri periudha kohe: atë para '39-ës me atë të '40- 44-ës dhe këtë me kohën e sotshëme(It is worth mentioning that its collection contributes to the history of our literature, which sooner or later has to be written with a lucidity of mind without any kind 0 judgement as a collection of literary documents able to present the circumstances of that time. "Shkëndija" will appear as a chain that connects three time periods: the pre - '39 to that of '40 es - 44 -es and this with today. 


\subsection{Journal "Shêjzat"}

After the failure of countless efforts of a large group of Albanian intellectuals and patriots to realize a safe and peaceful future, everything was overthrown for whole years.

"Fatkeqsija ma e madhe e rracës shqiptare qindron në dasit qi ndodhjet historike shkaktuen në trup të saj. Këto dasi i pasqyron vetë zhvillimi i letrësis, e cila zuni fill e u mëkamb n'ujdheza të shkëputuna njana prej tjetrës në hapësi dhe të ndërprëme në kohë". ${ }^{17}$ (The major disaster of the Albanian race results of the divisions and segmentations that historical occurrences caused to its body. These divisions are reflected in the development of our literature, which originated and continued their way in fragmented paths in space and interrupted in time". To approve this quotation, Koliqi considers Buzuku as a solitary phenomenon, that even today is not known whether he was an initiator or a sequential of a literary activity in Albanian language. Then he continues with Matranga, who developed his activity without knowing Buzuku; Bogdani, who in his writings did not mention neither Bardhi nor Budi, and this happens with these figures known as the founders of Albanian literature. Such a phenomenon occurs even with De Rada, who published his creations without knowledge of the other Albanian authors and continuing with other authors as De Rada, Fishta, and Naimi. All this would serve to Koliqi as to say that the same phenomenon was happening at that time. Literature was developed in three directions: the Albanian state, Kosovo and Diaspora, which included the Arbëresh of Italy. All these three developed in directions that did not match with each other, it's mostly official Albanian who developed almost completely different from the other two directions.

Already an immigrant forced to live in foreign lands, as Koliqi noted that hopes for free Albania were quite distant, "..tue shkue vjetët u kujtuem se shartet ndërkombtare nuk lêjojshin me shpresue shpejt këthimin e Shqipnis në nji gjendje të rendomtë qytetare, edhe atëherë filloi ndër ne m'u shfaqë ideja se intelektualët e mërgatës do të kërkojshin udha të reja për të qindrue në rreth e në frymë të jetës shpirtnore të kombit." (... as the years passed, we recalled that international laws did not allow that Albania turned into an ordinary civic situation, it was just at that time that we were shown the idea that intellectual immigrants would search new paths to stay within the spiritual life of the nation. "The fear that unawares detachment from heart rate would remove the immigrant and with together with them even prof . Koliqi, encouraged him to seek a solution that would serve the preservation of cultural values and heritage and at the same time would somehow help in solving the national question. He could not stay without doing anything. Equipped with the experience of previous editions, the heart and mind worked for the creation of a new journal, which would gather around it intellectual minds, and together realize the above goal. When Martin Camaj arrived in Italy, a ray of light shined for Koliqi. Very soon strongly supported by Camaj, a youngster with quite a new perspective, student of the honourable Professor Henrik Bariç affirmed in Kosovo with the first literary creations"pasi kishte thithur njomësinë agimore të lëtërsisë së Kosovës"( after beeing equipped with the fresh touch of the literature of Kosovo), Koliqi realizes the desire for the publication of the journal "Shejzaf", which miraculously quite quickly, exceeded any expectations of the founders . Ajo frymë më rinoi e shkaktoi në mue nji ringjallje fuqish. Pinjuell i nji breznije tjetër, ndjekës i asaj rrymbe qi pat Fishtën e Mjedjen për mjeshtra, unë ndiejshem nevojën m'u përtri letrarisht, m'u vu me hap t'em në rrythem të kohës së rë, natyrisht pa u zhgulë nga rrajët ë vjetra, m'u zhytë në lulzim prendveruer qi cilëson letrësin e Kosovës si n'ujna mrekullbasë qi këthejnë shpirtin në stinën e prillit të jetës"18.( That breath filled me with youthfulness and power revival. As an offspring of another generation, as a follower of the stream that Mjeda and Fishat as masters followed, I deeply need the need to revive literary, to step in the new era, without taking off my roots, and eventually sink into the blosom of spring that qualifies the literature of Kosovo as being part of miracle that brings spring to the soul).

Meanwhile, "Shêjzat" was recovered also under the influence of the heritage of Arbëresh of Italy and freshness that the young writers of Kosovo brought.

The aim of the founders of the journal was very ambitious. It was directed by the synthesis of ethnic literary values of the past and present, excluding their ideological source. "Për ne shkâ përfshin të të Bùkurit \{le Beau) asht edhe gja e mirë, asht edhe rreze e së Vërtetës."(To us what consists of beauty\{ le Beau )is a good thing and a beam of truth. "

The way of compilation and style of the journal would be simple, which would allow reading by all.

The spiritual leaders must have been the Renaissance writers, whose movement, "... e nxori nga errësija në dritë të liris Shqipnin, tue e naltue idealin e atdheut mbi besime e mbi krahina." (... brought Albania from darkness into the freedom of light, praising the ideal of the Homeland on beliefs over the country. "

17 Ibid,pg.307.

${ }^{18}$ the same, pg 308. 
The movement of ethnic roots should remain insatiable. Gjaku i ynë i shprishun (i shpërdam) në të katër kandet e rrokullis toksore vion me rrahje të njajta ku flitet shqip dhe ku zhvillohet jeta në nderim të dokevet të të Parvet. Shqipnija e vërtetë s'ka kufij.". (Albanian hearts beat the same where Albanian language is spoken and where life is, honoring the roots of ancestors. Real Albania has no borders.)

The journal would be nationwide and would be designed to follow the example of the great national writers such as Naim and Sami Frashëri, Vaso Pasha, Jani Vreto, Father Gjergj Fishta, etc. , who knew quite well how to stimulate union and overcome religious divisions .

There would be neither exclusive nor excluding in this journal. Everyone would be free to express his or her own opinion without discrimination or bias, as far as it would not violate the principles and purposes upon which the journal was built, whose title preferably coincided with its Mission - Hyllësi vyrtytetsh Arbnore. "Ne besojmë, shkurt në vërtytet e mshefta të gjakut shqiptar. Këto vërtyte flêjnë, duhen zgjue e këndellë. Në kët vepër pêrtrise, përmbledhet detyra e çdo shqiptari atdhêdashës por sidomos e inteltualvef' ${ }^{19}$. ( We believe simply in the hidden values of the Albanian blood. These values sleep. Thus we should awake them. In this summarizing work it is reviewed the work of every Albanian patriotic but especially of Albanian intellectuals"

One of the objectives was the integration of the most prominent personalities and the most eminent Albanologists as honorary associates of the journal. Thanks to the excellent minds of the leaders, well-known dignitaries of linguistics and history joined the journal's such as: K. Gurakuqi, P. Jak Marlekaj o.f.m, the Arbëresh Rozolin Petrotta, Zef Schiró Junior jr, G. Gradilione, C. Haebler, A. Schmaus, H.J. Kissling, G. Stadtmüller, Z. Valentini, Peter Bartl, M. Gurakuqi etc.

To accomplish this task, the directors of the journal call the coworkers to add the cooperation and the support of the willing compatriots to their work. "The brave has good friends". 